\title{
INTEGRATION OF SUNFLOWER (Helianthus annuus) RESIDUES WITH A Pre-Plant Herbicide Enhances weed Suppression in Broad Bean (Vicia faba) $^{1}$
}

\author{
Integração de Resíduos de Girassol (Helianthus annuus) com Herbicida Pré-Emergente na \\ Supressão de Plantas Daninhas na Cultura da Fava (Vicia faba)
}

ALSAADAWI, I.S. ${ }^{2}$, KHALIQ, A. ${ }^{3}$, AL-TEMIMI, A.A. ${ }^{2}$ and MATLOOB, A. ${ }^{3}$

\begin{abstract}
Field trial was conducted with the aim of utilizing allelopathic crop residues to reduce the use of synthetic herbicides in broad bean (Vicia faba) fields. Sunflower residue at 600 and $1,400 \mathrm{~g} \mathrm{~m}^{-2}$ and Treflan (trifluralin) at 50, 75 and $100 \%$ of recommended dose were incorporated into the soil alone or in combination with each other. Untreated plots were maintained as a control. Herbicide application in plots amended with sunflower residue had the least total weed count and biomass, which was even better than herbicide used alone. Integration of recommended dose of Treflan with sunflower residue at $1,400 \mathrm{~g} \mathrm{~m}^{-2}$ produced maximum (987.5 $\mathrm{g} \mathrm{m}^{-2}$ ) aboveground biomass of broad bean, which was 74 and $36 \%$ higher than control and recommended herbicide dose applied alone, respectively. Combination of herbicide and sunflower residue appeared to better enhance pod number and yield per unit area than herbicide alone. Application of 50\% dose of Treflan in plots amended with sunflower residue resulted in similar yield advantage as was noticed with $100 \%$ herbicide dose. Chromatographic analysis of residue-infested field soil indicated the presence of several phytotoxic compounds of phenolic nature. Periodic data revealed that maximum suppression in weed density and dry weight synchronized with peak values of phytotoxins observed 4 weeks after incorporation of sunflower residues. Integration of sunflower residues with lower herbicide rates can produce effective weed suppression without compromising yield as a feasible and environmentally sound approach in broad bean fields.
\end{abstract}

Keywords: Allelopathy, sunflower residues, herbicide, phytotoxins, weeds, broad bean.

\begin{abstract}
RESUMO - O experimento foi realizado com o objetivo de utilizar resíduos agrícolas com potencial alelopático para reduzir o uso de herbicidas sintéticos em fava (Vicia faba). Resíduos de girassol (600 e 1,400 $\mathrm{g} \mathrm{m}^{-2}$ ) e Treflan (50, 75 e 100\% da dose recomendada) foram incorporados ao solo isoladamente ou em combinação uns com os outros. Parcelas não tratadas foram mantidas como controle. A aplicação de herbicidas nas parcelas com residuo de girassol, foi melhor do que o herbicida usado sozinho. A integração da dose recomendada de Treflan com residuo de girassol em 1,400 $\mathrm{g} \mathrm{m}^{-2}$, para a produção de biomassa aérea da fava, foi 74 e 36\% maior que o controle e a dose recomendada do herbicida aplicado isoladamente, respectivamente. Combinação de herbicida e resíduos de girassol são superiores no aumento do número de vagens e produtividade de fava, quando comparado ao herbicida isolado. Aplicação de 50\% da dose Treflan em parcelas com resíduo de girassol resultou em maior rendimento de grãos, semelhantemente a dose\% de herbicida. Análise cromatográfica do solo com o residuo de girassol indicou a presença de diversos compostos fitotóxicos de natureza fenólica. A supressão máxima da densidade e massa seca das plantas daninhas foram sincronizados com os valores de pico de fitotoxinas observados 4 semanas após a incorporação dos residuos de girassol. A integração de residuos de girassol com menores taxas de herbicida Treflan, pode suprimir plantas daninhas de forma mais eficaz, sem comprometer o rendimento da cultura da fava, como uma abordagem viável e ambientalmente racional.
\end{abstract}

Palavras-chave: alelopatia, resíduos de girassol, herbicida, fitotoxinas, plantas daninhas, fava.

1 Recebido para publicação em 15.3.2011 e aprovado em 17.6.2011.

2 Department of Biology, College of Science, Baghdad University, Baghdad, Iraq; ${ }^{3}$ Department of Agronomy, University of Agriculture, Faisalabad-38040, Pakistan, <khaliquaf@gmail.com>. 


\section{INTRODUCTION}

Weed infestation in field crops is a key issue contributing to direct loss in quality and quantity of produce, and weeds are identified as the most omnipresent class of pests interfering with crop plants through competition and allelopathy. Chemical control is an efficient method to control weeds and accounts for twothirds of total pesticide usage in the world. However, increasing thrust for organically produced commodities, public awareness about health and environmental concerns, and many other issues associated with indiscriminate use of herbicides demand something new that is less pesticide-dependent than existing farming systems (Uremis et al., 2009).

Integrating weed control practices with cultural measures can have a broader impact on weeds and should be synchronized with other crop production practices that influence agro-ecosystems. Such measures are comprised of planting time, (surface or incorporated) mulching, intercropping, row spacing and seeding densities, just to name a few. Residues of many crops are allelopathic and exhibit toxicity on decay (Chou, 1999). Soil incorporation or surface application as mulch of allelopathic crop residues affects weed dynamics by reducing/delaying seed germination and establishment, and suppressing individual plant growth hence contributing to overall decline in the density and vigor of the weed community (Gallandt et al., 1999). These residues can be exploited for weed suppression, and thus be helpful in reducing reliance on herbicides (Weston, 1996). Such an approach can help bring about the deleterious effects of current agricultural practices and cost of high energy inputs in agroecosystems (Singh et al., 2003).

Herbicides applied along with allelopathic products could have supportive action (Bhowmik \& Inderjit, 2003). Cheema et al. (2005) while working on a number of field crops as wheat, cotton, maize, rice and mung bean in Pakistan showed fair degree of success in reducing herbicide doses through tank mixing with allelopathic water extracts of sorghum and sunflower. Such water extracts were prepared by using crop residues of these crops (Cheema $\&$ Khaliq, 2000). It is hypothesized that the same fact can be true if such residues are directly applied to the field in a suitable way and dose. Little is known about the suspected complementary interaction between allelopathic crop residues and reduced herbicide rates. Allelopathic interactions are species specific, and concentration-dependent, and the suppression magnitude obtained is proportional to the applied dose (Khanh et al., 2005). Sunflower is a potent allelopathic crop and adversely affects weeds (Leather, 1983; Anjum \& Bajwa, 2007).

The present work aims to use allelopathic crop residues to reduce use of synthetic herbicides in broad bean (Vicia faba).

\section{MATERIAL AND METHODS}

\section{Sources of seeds and herbicides}

Seeds of sunflower cv. Coupan and broad bean cv. Kubrisi were obtained from the Department of Crop Production, College of Agriculture, Baghdad University. Treflan was purchased from the local market.

\section{Preparation of sunflower residues}

To prepare residues of plants of sunflower cv. Coupan, seeds were manually sown in $50 \mathrm{~cm}$ wide rows by maintaining $25 \mathrm{~cm}$ distance between seeds during the first fortnight of February, 2009. Fertilizers used were nitrogen as urea $(46 \% \mathrm{~N})$ at $240 \mathrm{~kg} \mathrm{ha}^{-1}$ and phosphorus as triple super phosphate $\left(46 \% \mathrm{P}_{2} \mathrm{O}_{5}\right)$ at $240 \mathrm{~kg} \mathrm{ha}^{-1}$. The whole phosphorus and half of the nitrogen were applied at planting while the remaining half of the nitrogen was applied after two weeks. At physiological maturity, heads were removed and the plants were harvested, airdried for several days under sun light and chopped into $2-3 \mathrm{~cm}$ pieces. Chopped material was kept under room condition until use.

\section{Efficacy of sunflower residues in combination with different rates of herbicides on weeds and broad bean}

The experiment was conducted in a field $180 \mathrm{~km}$ south of Baghdad, Iraq. The soil was calcareous clay loam with values of $\mathrm{pH}, \mathrm{Ec}$, 
Organic carbon, $\mathrm{NO}_{3}-\mathrm{N}, \mathrm{NH}_{4}-\mathrm{N}, \mathrm{K}$ and $\mathrm{P}$ equal to $7.9,3.3 \mathrm{dS} \mathrm{m}^{-1}, 0.4 \%, 58 \mathrm{ppm}, 450 \mathrm{ppm}$, $0.52 \%$ and $19 \%$ respectively.

Field plots $(100 \times 100 \mathrm{~cm})$ were selected randomLy in field where previous field history showed heavy weed infestation. These plots were plowed by a spade to a depth of $30 \mathrm{~cm}$. Nitrogen as urea $(46 \% \mathrm{~N})$ at $200 \mathrm{~kg} \mathrm{ha}^{-1}$ and phosphorus as triple super phosphate $(46 \%$ $\left.\mathrm{P}_{2} \mathrm{O}_{5}\right)$ at $200 \mathrm{~kg} \mathrm{ha}^{-1}$ were applied to the plots. All phosphorus and half of the nitrogen were applied at planting during seed bed preparation. while remaining nitrogen was applied after two weeks. Treatments were comprised of sunflower residue incorporated at different rates (600 and $1,400 \mathrm{~g} \mathrm{~m}^{-2}$ ) and different doses (100, 75 and $50 \%$ ) of Treflan applied at 750 , 652.5 and $375 \mathrm{~mL} \mathrm{ha}^{-1}$. These were used either alone or in combination with each other. A control without sunflower residue and herbicide application was maintained for comparison. The experiment was conducted in randomized complete block design under split plot arrangement with four replications. The herbicide rates were kept in the main plots while sunflower residue rates were assigned to subplots.

Sunflower residues were incorporated at sowing in the respective plots as per treatment. Treflan was also applied as pre plant soil incorporation. Volume of spray (300 $\mathrm{L} \mathrm{ha}^{-1}$ ) was calibrated using water. Different doses of Treflan were applied using a Knapsack hand sprayer fitted with T-Jet nozzle at a pressure of $207 \mathrm{k} \mathrm{Pa}$. Seeds of broad bean cv. Kubrisi were manually sown in all plots in $25 \mathrm{~cm}$ spaced rows keeping $20 \mathrm{~cm}$ distance between plants (20 plants per plot) All plots received equal irrigated water during the entire course of study.

At physiological crop maturity (150 days after sowing), individual weed counts per plot were made. Weeds were clipped from ground surface, and dried in an oven at $70^{\circ} \mathrm{C}$ for $72 \mathrm{~h}$; the dry weight of individual weed was recorded.

Data regarding broad bean crop, plant height $(\mathrm{cm})$, oven-dried biomass $\left(\mathrm{g} \mathrm{m}^{-2}\right)$, number of branches per plant, number of pods $\left(\mathrm{m}^{-2}\right)$, number of seeds per pod and weight of 100-seeds (g) were recorded using standard procedures.

The data were analyzed using analysis of variance (ANOVA), the mean values were separated using least significant difference (LSD) at $\mathrm{P} \leq 0.05$ (Steel et al., 1997).

\section{Isolation, identification and quantification of phytotoxins in the decomposing sunflower residues in soil}

Soil samples minus litter were taken from different sites of broad bean field. The soil samples were mixed thoroughly and air dried. Air dried sunflower plant materials were chopped into pieces of $2-3 \mathrm{~cm}$ length and incorporated into the soil at a rate of $7 \mathrm{~g} \mathrm{~kg}^{-1}$ soil. The mixture was packed in a plastic pot of $10 \mathrm{~kg}$ capacity, irrigated with water to field capacity, covered with perforated plastic cover to avoid evaporation and placed in the field at the beginning of the growing season of broad bean. Biweekly, soil samples were taken from the pot using metal soil borer, mixed thoroughly and stored in deep freeze until use.

As extraction procedure, $1 \mathrm{~g}$ of soil sample was extracted with $100 \mathrm{~mL}$ of distilled water using the method of Harborne (1973). The water extract was acidified with $1 \mathrm{~mL}$ of acetic acid. The mixture was heated gently, mixed thoroughly by ultrasonic apparatus to exclude air bubbles from the residues and allowed to stand for $4 \mathrm{~h}$. The mixture of each sample was filtered by filter paper under vacuum condition and kept in a refrigerator until use.

For identification purposes, $50 \mu \mathrm{L}$ of the extract was injected in Reversed Phase Liquid Chromatogram (RVLC Shimadzu-C-6A) using the procedure outlined by Hartley and Buchan (1979). The conditions of separation are listed in Table 1 . The peaks were detected by a UV detector. Standards of suspected phytotoxins were run similarly for identification and quantification. Concentration of each isolated compound was determined by the following equation:

$$
\text { Concentration }(\mathrm{ppm})=\frac{\text { Area of the sample }}{\text { Area of the standard }} \times \text { Concentration of the standard } \times \text { Dilution factor }
$$


Table 1 - Separation conditions for determination of phytotoxins in decomposing sunflower residues

\begin{tabular}{|l|l|}
\hline \multicolumn{1}{|c|}{ Parameter } & \multicolumn{1}{|c|}{ Characteristic } \\
\hline Column dimensions & 50 length $\mathrm{x} 2.6 \mathrm{~mm}$ i.d \\
\hline Diatomite & Supleco wax 10 \\
\hline Attenuation & $0.01 \mathrm{ppm}$ \\
\hline Rate of recorder & $10 \mathrm{~mm} \mathrm{~min}^{-1}$ \\
\hline Detector & $\mathrm{SPD}-2010$ spectrophotometer at $254 \mathrm{~nm}$ \\
\hline Volume injection sample & $50 \mu \mathrm{L}$ \\
\hline Type of Column & NS-C18 \\
\hline Mobile phase & $1 \%$ acetic acid in $\mathrm{H}_{2} \mathrm{O}:$ acetonitrite $30: 7(\mathrm{v} / \mathrm{v})$ \\
\hline Temperature & $35^{\circ} \mathrm{C}$ \\
\hline
\end{tabular}

\section{RESULTS AND DISCUSSION}

\section{Effect of various treatments on weeds grown in broad bean field}

Weed flora of the experimental site was comprised mainly of Avena fatua, Melilotus indicus, Beta vulgaris and Centaurea bruguierana. Both herbicide rates and residue application posed significant suppressive effects on the number of these weeds (Table 2). Significant interaction was observed for herbicide dose and residues rates regarding $A$. fatua and $M$. indicus. Residue incorporation at 600 and $1,400 \mathrm{~g} \mathrm{~m}^{-2}$ resulted in 37 and $63 \%$ control of A. fatua, 37 and $50 \%$ control of $M$. indicus, 56 and $67 \%$ control of $B$. vulgaris cicla, and 33 and $67 \%$ control of that of $C$. bruguierana. Pre plant soil incorporation of Treflan caused linear reduction in weed number per unit area with increasing application rates. However, weed density was suppressed to an even greater extent when herbicide was applied in plots where sunflower residue had been incorporated. Herbicide and residue showed complementary interaction and recorded $22-37 \%$ more suppression of $A$. fatua than the recommended dose. Similarly, 29-67\% more suppression of $M$. indicus was noticed due to integration of herbicide with sunflower residues. Reduced herbicide doses (50 and $75 \%$ ) in combination with sunflower residue scored greater weed suppression than that realized with the recommended dose used alone.

The recommended dose of herbicide when applied to plots incorporated with sunflower residues at 1,400 $\mathrm{g} \mathrm{m}^{-2}$ scored 53, 49 and 100\% more biomass suppression of A. fatua, $M$. indicus, $B$. vulgaris cicla and $C$. bruguierana, respectively, than the herbicide dose used alone (Table 3). Reduced herbicides rates used in plots where sunflower residues had been applied resulted in even higher reduction in weed dry matter accumulation as compared with plots where such doses were used alone. The use of $75 \%$ of the recommended dose of herbicide coupled with $600 \mathrm{~g} \mathrm{~m}^{-2}$ sunflower residue scored statistically similar suppression of biomass of all four weeds compared to that achieved with the same herbicide dose applied alone. Significant herbicide dose $\mathrm{x}$ residue rate interaction was also obvious for total weed count and biomass in broad bean field (Tables 4 and 5). Herbicide application in plots with sunflower residue $\left(600\right.$ and $\left.1,400 \mathrm{~g} \mathrm{~m}^{-2}\right)$ reduced total weed count and biomass by $24-62 \%$ and $26-59 \%$ as compared to herbicide used alone. The reduction over control for the same treatments amounted to $75-87 \%$ and $86-$ $92 \%$. Interestingly, a worthwhile suppression that was greater even than the recommended herbicide dose was also delivered by $75 \%$ herbicide dose + sunflower residues applied at $1,400 \mathrm{~g} \mathrm{~m}^{-2}$. Herbicide doses (75 and 50\%) along with 600 and $1,400 \mathrm{~g} \mathrm{~m}^{-2}$ sunflower residues produced as good weed suppression as was observed under sole application of the recommended herbicide dose.

Results suggest that all treatments suppressed weed count as well as biomass over control. Incorporation of sunflower residues into the soil accounted for substantial weed suppression. Reduced weed count and biomass was reflective of the inhibitory effects of 
Table 2 - Effects of different rates of herbicides and sunflower residues cv. Coupan on number of weeds grown in broad bean field

\begin{tabular}{|c|c|c|c|c|}
\hline \multirow{2}{*}{ Herbicide dose } & \multicolumn{4}{|c|}{ Residue rates $\left(\mathrm{g} \mathrm{m}^{-2}\right)$} \\
\hline & 0 & 600 & 1,400 & Average \\
\hline \multicolumn{5}{|c|}{ Avena fatua } \\
\hline $0 \%$ (Control) & 305.0 & 192.5 & 113.5 & 203.7 \\
\hline $50 \%$ & 142.0 & 94.5 & 74.5 & 103.7 \\
\hline $75 \%$ & 109.5 & 88.5 & 62.5 & 86.8 \\
\hline $100 \%$ & 94.0 & 73.5 & 37.5 & 68.3 \\
\hline Average & 162.6 & 112.3 & 72.0 & \\
\hline $\mathrm{LSD}=0.05$ & Herbicide dose $=11.71$ & Residue rates $=9.46$ & \multicolumn{2}{|c|}{ Herbicide dose $\times$ Residue rates $=19.11$} \\
\hline \multicolumn{5}{|c|}{ Melilotus indicus } \\
\hline $0 \%$ (Control) & 72.0 & 45.5 & 36.0 & 51.2 \\
\hline $50 \%$ & 36.0 & 35.0 & 31.0 & 34.0 \\
\hline $75 \%$ & 34.0 & 26.0 & 14.0 & 24.7 \\
\hline $100 \%$ & 31.5 & 22.5 & 10.5 & 21.5 \\
\hline Average & 43.8 & 32.3 & 22.9 & \\
\hline $\mathrm{LSD}=0.05$ & Herbicide dose $=4.1$ & Residue rates $=2.95$ & \multicolumn{2}{|c|}{ Herbicide dose $\times$ Residue rates $=6.57$} \\
\hline \multicolumn{5}{|c|}{ Beta vulgaris cicla } \\
\hline $0 \%$ (Control) & 4.5 & 2.0 & 1.5 & 2.7 \\
\hline $50 \%$ & 2.0 & 1.0 & 0.5 & 1.2 \\
\hline $75 \%$ & 1.0 & 0.5 & 0.5 & 0.6 \\
\hline $100 \%$ & 0.5 & 0.5 & 0.0 & 0.3 \\
\hline Average & 2.0 & 1.0 & 0.6 & \\
\hline $\mathrm{LSD}=0.05$ & Herbicide dose $=0.57$ & Residue rates $=0.47$ & \multicolumn{2}{|c|}{ Herbicide dose $\times$ Residue rates $=$ NS } \\
\hline \multicolumn{5}{|c|}{ Centaurea bruguierana } \\
\hline $0 \%$ (Control) & 6.0 & 4.0 & 2.0 & 4.0 \\
\hline $50 \%$ & 4.0 & 3.0 & 0.5 & 2.5 \\
\hline $75 \%$ & 2.0 & 2.0 & 0.0 & 1.3 \\
\hline $100 \%$ & 1.0 & 0.5 & 0.0 & 0.5 \\
\hline Average & 3.3 & 2.8 & 0.6 & \\
\hline $\mathrm{LSD}=0.05$ & Herbicide dose $=0.96$ & Residue rates $=0.95$ & \multicolumn{2}{|c|}{ Herbicide dose $\times$ Residue rates $=$ NS } \\
\hline
\end{tabular}

Treflan applied at a rate of $750 \mathrm{~mL} \mathrm{ha}^{-1}$. Each number is an average of 4 replicates.

sunflower residue incorporation mediated by the presence of phytotoxic allelochemicals in these residues, which were released by decomposition in their immediate vicinity (Birkett et al., 2001). Sunflower is reported to contain several allelochemicals responsible for biological activity, viz, chlorogenic acid, isochlorogenic acid, á-naphthol, scopolin, and annuionones (Macias et al., 2002; Anjum \& Bajwa, 2005). Inhibitory activity of sunflower allelochemicals against broad-leaved weeds has been reported by Leather (1983) and Anjum \& Bajwa (2007), and described as selective in nature (Khanh et al., 2005). Most of these allelochemicals are water soluble and when imbibed by the germinating weed seeds, hampered their germination and subsequent seedling growth, thus contributing to overall decline in the density, vigor and stand establishment of the weed community (Gallandt et al., 1999). Greater weed inhibition was observed at higher residue incorporation rates. Khanh et al. (2005) pointed that suppression magnitude in allelopathic interactions is directly proportional to the applied dose.

Treflan belongs to the dinitroaniline herbicide group that acts as mitotic inhibitor by disrupting cell division through interference 
Table 3 - Effects of different rates of herbicides and sunflower residues cv. Coupan on biomass of weeds grown in broad bean field

\begin{tabular}{|c|c|c|c|c|}
\hline \multirow{2}{*}{ Herbicide dose } & \multicolumn{4}{|c|}{ Residue rates $\left(\mathrm{g} \mathrm{m}^{-2}\right)$} \\
\hline & 0 & 600 & 1,400 & Average \\
\hline \multicolumn{5}{|c|}{ Avena fatua } \\
\hline $0 \%$ (Control) & $1,145.0$ & 854.0 & 378.5 & 792.5 \\
\hline $50 \%$ & 347.0 & 272.0 & 225.5 & 281.5 \\
\hline $75 \%$ & 313.0 & 231.5 & 179.0 & 241.2 \\
\hline $100 \%$ & 242.5 & 181.5 & 112.5 & \\
\hline Average & 511.9 & 384.8 & 223.9 & \\
\hline $\mathrm{LSD}=0.05$ & Herbicide dose $=9.97$ & Residue rates $=10.13$ & \multicolumn{2}{|c|}{ Herbicide dose $\times$ Residue rates $=17.07$} \\
\hline \multicolumn{5}{|c|}{ Melilotus indicus } \\
\hline $0 \%$ (Control) & 350.5 & 132.0 & 80.5 & 187.7 \\
\hline $50 \%$ & 76.5 & 72.0 & 72.0 & 73.5 \\
\hline $75 \%$ & 73.0 & 65.5 & 39.0 & 59.2 \\
\hline $100 \%$ & 69.5 & 60.5 & 35.5 & 55.2 \\
\hline Average & 142.4 & 82.5 & 56.8 & \\
\hline $\mathrm{LSD}=0.05$ & Herbicide dose $=4.94$ & Residue rates $=2.87$ & \multicolumn{2}{|c|}{ Herbicide dose $\times$ Residue rates $=7.74$} \\
\hline \multicolumn{5}{|c|}{ Beta vulgaris } \\
\hline $0 \%$ (Control) & 160.0 & 56.5 & 48.5 & 88.3 \\
\hline $50 \%$ & 74.0 & 31.5 & 13.0 & 39.5 \\
\hline $75 \%$ & 32.5 & 13.0 & 12.5 & 19.3 \\
\hline $100 \%$ & 12.5 & 10.0 & 0.0 & 7.5 \\
\hline Average & 69.8 & 27.8 & 24.7 & \\
\hline $\mathrm{LSD}=0.05$ & Herbicide dose $=22.83$ & Residue rates $=25.40$ & \multicolumn{2}{|c|}{ Herbicide dose $\times$ Residue rates $=40.09$} \\
\hline \multicolumn{5}{|c|}{ Centaurea bruguierana } \\
\hline $0 \%$ (Control) & 221.5 & 84.0 & 30.0 & 111.8 \\
\hline $50 \%$ & 121.0 & 40.0 & 12.5 & 57.8 \\
\hline $75 \%$ & 78.5 & 34.0 & 0.0 & 37.5 \\
\hline $100 \%$ & 34.5 & 15.0 & 0.0 & 16.5 \\
\hline Average & 113.9 & 43.3 & 10.6 & \\
\hline $\mathrm{LSD}=0.05$ & Herbicide dose $=44.83$ & Residue rates $=32.09$ & \multicolumn{2}{|c|}{ Herbicide dose $\times$ Residue rates $=60$} \\
\hline
\end{tabular}

Treflan applied at a rate of $750 \mathrm{~mL} \mathrm{ha}^{-1}$. Each number is an average of 4 replicates.

Table 4 - Effects of different rates of herbicides and sunflower residues cv. Coupan on total weed number in broad bean field

\begin{tabular}{|l|c|c|c|c|}
\hline \multirow{2}{*}{ Herbicide dose } & \multicolumn{4}{|c|}{ Residue rates $\left(\mathrm{g} \mathrm{m}^{-2}\right)$} \\
\cline { 2 - 5 } & 0 & 600 & 1,400 & Average \\
\hline $0 \%$ (Control) & 378.5 & 244.5 & 153.0 & 258.7 \\
\hline $50 \%$ & 184.0 & 133.5 & 106.5 & 141.3 \\
\hline $75 \%$ & 146.5 & 117.0 & 76.5 & 90.5 \\
\hline $100 \%$ & 127.0 & 96.5 & 48.0 & 96.0 \\
\hline Average & 209.0 & 147.9 & Herbicide dose $\times$ Residue rates $=18.78$ \\
\hline LSD $=0.05$ & Herbicide dose $=11.17$ & Residue rates $=10.50$ & Ryyy \\
\hline
\end{tabular}

Treflan applied at a rate of $750 \mathrm{~mL} \mathrm{ha}^{-1}$. Each number is an average of 4 replicates. 
Table 5 - Effects of different rates of herbicides and sunflower residues cv. Coupan on total weed biomass in broad bean field

\begin{tabular}{|c|c|c|c|c|}
\hline \multirow{2}{*}{ Herbicide dose } & \multicolumn{4}{|c|}{ Residue rates $\left(\mathrm{g} \mathrm{m}^{-2}\right)$} \\
\hline & 0 & 600 & 1,400 & Average \\
\hline $0 \%$ (Control) & $1,877.0$ & $1,126.5$ & 537.5 & $1,180.3$ \\
\hline $50 \%$ & 618.5 & 415.5 & 323.0 & 452.3 \\
\hline $75 \%$ & 497.0 & 344.0 & 230.5 & 357.2 \\
\hline $100 \%$ & 359.0 & 267.0 & 148.0 & 258.0 \\
\hline Average & 837.9 & 538.3 & 309.8 & \\
\hline $\mathrm{LSD}=0.05$ & Herbicide dose $=49.1$ & Residue rates $=35.9$ & \multicolumn{2}{|c|}{ Herbicide dose $\times$ Residue rates $=78.9$} \\
\hline
\end{tabular}

Treflan applied at a rate of $750 \mathrm{~mL} \mathrm{ha}^{-1}$. Each number is an average of 4 replicates.

with microtubule assembly and kills germinating seeds rather than seedlings. Pre-plant incorporation of Treflan was quite effective in reducing count and biomass in broad bean filed over control. The suppression magnitude obtained was obvious at higher application rates than at lower rates i.e., 50 and $75 \%$ of the recommended dose. However, when herbicide application whether at low or recommended dose was made to plots amended with sunflower residues, greater weed suppression than sole application of herbicide was achieved (Table 3). Maximum suppression was obtained by integrating the recommended dose of Treflan with sunflower residue at $1,400 \mathrm{~g} \mathrm{~m}^{-2}$. This confirmed the previous hypothesis proposed by Bhowmik and Inderjit (2003) that herbicides applied in combination with allelopathic conditions could have a complementary interaction, and may help to minimize herbicide usage for weed management in field crops. It seems that a reduced level of herbicide may be feasible for providing satisfactory weed control when it works simultaneously with allelopathic conditions.

\section{Effect of various treatments on yield and yield components of broad bean}

Various weed control treatments improved the tested agronomic traits, yield and yield components of broad bean (Tables 6 and 7). A non-significant interaction was recorded for plant height, seeds per pod and 100-seed weight. Integration of the recommended dose of Treflan with sunflower residues at $1,400 \mathrm{~g} \mathrm{~m}^{-2}$ produced maximum $\left(987.5 \mathrm{~g} \mathrm{~m}^{-2}\right)$ aboveground biomass, which was 74 and $36 \%$ higher than control and recommended herbicide dose applied alone. Treflan at 50, 75 and $100 \%$ dose accompanied with sunflower residues at $1,400 \mathrm{~g} \mathrm{~m}^{-2}$ produced branches per plant that were similar to that recorded for the recommended herbicide dose. A bigger number of pods $\mathrm{m}^{-2}$ and greater yield over control was observed for all the treatments. However, combination of herbicide and sunflower residue appeared superior in enhancing pod number and yield per unit area than herbicide alone. Application of 50\% dose of Treflan in plots amended with sunflower residue resulted in similar yield advantage as was noticed at $100 \%$ herbicide dose. Maximum yield $\left(1,045 \mathrm{~g} \mathrm{~m}^{-2}\right)$ was harvested from plots applied with the recommended dose of Treflan + sunflower residue at $1,400 \mathrm{~g} \mathrm{~m}^{-2}$.

The promotion of yield and yield components of broad bean with efficient weed control treatments may be attributed to the supportive action of weed control techniques resulting in less competition of weeds for growth factors (Tables 5 and 6). Higher shoot biomass and a bigger number of branches and pods over control might be attributed to the greater availability of growth factors to broad bean plants.

\section{Phytotoxin isolation, identification and quantification}

Chromatographic analysis revealed the presence of chlorogenic, isochlorogenic, caffeic, gallic, syrinigic, hydroxyl benzoic, p-coumaric, ferulic and vanillic acids as product of sunflower residues decomposition (Table 8). Catechol was also observed. A significant amount of these phytotoxins was observed in 
Table 6 - Effects of different rates of herbicides and residues of sunflower cv. Coupan on some agronomic traits of broad bean

\begin{tabular}{|c|c|c|c|c|}
\hline \multirow{2}{*}{ Herbicide dose } & \multicolumn{4}{|c|}{ Residue rates $\left(\mathrm{g} \mathrm{m}^{-2}\right)$} \\
\hline & 0 & 600 & 1,400 & Average \\
\hline \multicolumn{5}{|c|}{ Plant height $(\mathrm{cm})$} \\
\hline $0 \%$ (Control) & 122.3 & 115.5 & 109.8 & 115.9 \\
\hline $50 \%$ & 108.0 & 106.0 & 105.0 & 106.3 \\
\hline $75 \%$ & 106.8 & 102.3 & 101.8 & 103.6 \\
\hline $100 \%$ & 102.3 & 100.0 & 98.0 & 100.1 \\
\hline Average & 109.9 & 105.6 & 103.7 & \\
\hline $\mathrm{LSD}=0.05$ & Herbicide dose $=3.37$ & Residue rates $=2.29$ & \multicolumn{2}{|c|}{ Herbicide dose $\times$ Residue rates $=$ NS } \\
\hline \multicolumn{5}{|c|}{ Shoot biomass $\left(\mathrm{g} \mathrm{m}^{-2}\right)$} \\
\hline $0 \%$ (Control) & 569.0 & 610.0 & 635.0 & 604.7 \\
\hline $50 \%$ & 617.5 & 645.0 & 715.0 & 659.2 \\
\hline $75 \%$ & 655.0 & 680.0 & 895.0 & 743.3 \\
\hline $100 \%$ & 724.0 & 762.5 & 987.5 & 824.7 \\
\hline Average & 641.4 & 674.4 & 808.1 & \\
\hline $\mathrm{LSD}=0.05$ & Herbicide dose $=66.0$ & Residue rates $=67.4$ & \multicolumn{2}{|c|}{ Herbicide dose $\times$ Residue rates $=82$} \\
\hline \multicolumn{5}{|c|}{ Number of branches per plant } \\
\hline $0 \%$ (Control) & 4.3 & 4.7 & 5.0 & 4.7 \\
\hline $50 \%$ & 5.3 & 4.9 & 6.4 & 5.5 \\
\hline $75 \%$ & 4.4 & 4.8 & 6.9 & 5.3 \\
\hline $100 \%$ & 4.5 & 6.2 & 6.4 & 5.7 \\
\hline Average & 4.6 & 6.0 & 6.2 & \\
\hline $\mathrm{LSD}=0.05$ & Herbicide dose $=$ NS & Residue rates $=0.67$ & \multicolumn{2}{|c|}{ Herbicide dose $\times$ Residue rates $=1.5$} \\
\hline
\end{tabular}

Treflan applied at a rate of $750 \mathrm{~mL} \mathrm{ha}^{-1}$. Each number is an average of 4 replicates.

residue incorporated soil. Hydroxy benzoic acid was found to be the predominant constituent (6.624 ppm) of residue decomposition products right from the beginning. Considerable amounts of caffeic, gallic, syrinigic, ferulic and vanillic acids were also observed. Dynamics of release, decomposition and degradation of phytotoxins into the soil was quite interesting as different phytotoxins showed differential behavior for these processes. Phytotoxins released into the soil, increased as time went by and reached their peak values 4 weeks after the incorporation of residues. During this period, maximum quantities of chlorogenic, isochlorogenic, caffeic, hydroxyl benzoic, ferulic and vanillic acids as well as that of catechol were observed. Afterwards, a sharp decline in the quantities of these phytotoxins was observed at 6 weeks that reached to almost negligible yet detectable values at 8 weeks. Gallic and syrinigic acid continued to increase up to 6 weeks and showed a decline thereafter. $\mathrm{P}$-coumaric acid was maximum (522 ppm) at
2 weeks, but it was not detected after 4 weeks as did ferulic acid.

Chromatographic analysis provided additional insight of residue mediated weed suppression by establishing qualitative and quantitative presence of different phytotoxins in sunflower cv. Coupan (Table 7). Such phytotoxins are reported to exert their adverse effects on ion uptake (Olmsted \& Rice, 1970), chlorophyll biosynthesis (Weir et al., 2004), disruption of cell membrane stability and cellular metabolism (Keck \& Hodges, 1973; Bogatek et al., 2005), protein and hormone biosynthesis (Holappa \& Blum, 1991), cell division, as well as bring changes in the ultrastructural components of cells (SanchezMoreiras et al., 2004). It is imperative to mention that the period indicating maximum quantities of these phytotoxins coincided with the period in which maximum suppressive activity against weeds was noticed, which explains the release, activity of phytotoxins on 
Table 7 - Effects of different rates of herbicides and sunflower residues cv. Coupan on yield and yield components of broad bean

\begin{tabular}{|c|c|c|c|c|}
\hline \multirow{2}{*}{ Herbicide dose } & \multicolumn{4}{|c|}{ Residue rates $\left(\mathrm{g} \mathrm{m}^{-2}\right)$} \\
\hline & 0 & 600 & 1,400 & Average \\
\hline \multicolumn{5}{|c|}{ Number of pods $\mathrm{m}^{-2}$} \\
\hline $0 \%$ (Control) & 149.5 & 172.0 & 212.5 & 178.00 \\
\hline $50 \%$ & 202.5 & 219.0 & 245.0 & 222.16 \\
\hline $75 \%$ & 213.5 & 251.0 & 282.0 & 248.83 \\
\hline $100 \%$ & 239.0 & 281.5 & 314.8 & 278.43 \\
\hline Average & 201.1 & 230.9 & 263.6 & \\
\hline $\mathrm{LSD}=0.05$ & Herbicide dose $=46.23$ & Residue rates $=28.30$ & \multicolumn{2}{|c|}{ Herbicide dose $\times$ Residue rates $=60.10$} \\
\hline \multicolumn{5}{|c|}{ Number of seeds pod ${ }^{-1}$} \\
\hline $0 \%$ (Control) & 2.13 & 2.05 & 2.47 & 2.22 \\
\hline $50 \%$ & 2.56 & 2.67 & 2.94 & 2.72 \\
\hline $75 \%$ & 2.00 & 2.73 & 2.76 & 2.50 \\
\hline $100 \%$ & 2.67 & 2.85 & 2.87 & 2.80 \\
\hline Average & 2.34 & 2.58 & 2.74 & \\
\hline $\mathrm{LSD}=0.05$ & Herbicide dose $=0.31$ & Residue rates $=0.30$ & \multicolumn{2}{|c|}{ Herbicide dose $\times$ Residue rates $=$ NS } \\
\hline \multicolumn{5}{|c|}{ Weight of 100 seeds $(\mathrm{g})$} \\
\hline $0 \%$ (Control) & 102.00 & 138.50 & 113.80 & 118.10 \\
\hline $50 \%$ & 106.80 & 121.50 & 111.75 & 113.35 \\
\hline $75 \%$ & 115.80 & 110.50 & 113.25 & 113.18 \\
\hline $100 \%$ & 106.00 & 108.00 & 114.25 & 109.42 \\
\hline Average & 107.65 & 119.62 & 113.26 & \\
\hline $\mathrm{LSD}=0.05$ & Herbicide dose $=$ NS & Residue rates $=$ NS & \multicolumn{2}{|c|}{ Herbicide dose $\times$ Residue rates $=$ NS } \\
\hline \multicolumn{5}{|c|}{ Plant yield $\left.\left(\mathrm{g} \mathrm{m}^{-2}\right)\right)$} \\
\hline $0 \%$ (Control) & 282.75 & 466.00 & 576.50 & 441.75 \\
\hline $50 \%$ & 638.75 & 706.00 & 700.70 & 681.82 \\
\hline $75 \%$ & 643.75 & 767.50 & 910.00 & 773.75 \\
\hline $100 \%$ & 671.25 & 853.25 & $1,045.00$ & 856.50 \\
\hline Average & 559.12 & 698.18 & 808.05 & \\
\hline $\mathrm{LSD}=0.05$ & Herbicide dose $=63.8$ & Residue rates $=88.5$ & \multicolumn{2}{|c|}{ Herbicide dose $\times$ Residue rates $=121.3$} \\
\hline
\end{tabular}

Treflan applied at a rate of $750 \mathrm{~mL} \mathrm{ha}^{-1}$. Each number is an average of 4 replicates.

Table 8 - Isolation, identification and quantification of phytotoxins of decomposed sunflower residues in soil at different periods of decomposition

\begin{tabular}{|c|c|c|c|c|c|}
\hline \multirow{3}{*}{ Phenolic acids } & \multicolumn{5}{|c|}{ Concentration (ppm) } \\
\hline & \multicolumn{5}{|c|}{ Decomposition periods (weeks) } \\
\hline & 0 & 2 & 4 & 6 & 8 \\
\hline Chlorogenic acid & 93.23 & 48.86 & 76.23 & 37.46 & 0.59 \\
\hline Isochlorogenic acid & 29.26 & 85.30 & 112.06 & 1.19 & 0.02 \\
\hline Caffeic acid & 164.58 & 316.28 & 553.15 & 265.09 & 3.93 \\
\hline Gallic acid & 126.23 & 349.16 & 458.73 & 665.07 & 0.26 \\
\hline Syringic acid & 91.51 & 314.40 & 236.52 & 756.36 & 3.97 \\
\hline Hydroxy benzoic acid & 394.68 & 386.02 & 6624.27 & 179.55 & 5.46 \\
\hline P- coumaric acid & 110.95 & 521.77 & 213.41 & 0.00 & 0.00 \\
\hline Ferulic acid & 84.59 & 311.50 & 441.69 & 0.00 & 0.00 \\
\hline Vanillic acid & 120.33 & 342.40 & 494.35 & 238.52 & 13.44 \\
\hline Catechol & 85.13 & 206.82 & 289.20 & 0.00 & 3.52 \\
\hline Total & $1,300.49$ & $2,882.15$ & $9,499.61$ & $2,143.24$ & 31.37 \\
\hline
\end{tabular}

Average of two replicates. 
weed suppression. For practical application, it is very important that in order to achieve a fair amount of suppression through allelopathic crop residues, maximum level of phytotoxins entering into the soil should encounter the germination and early growth period of weeds while they are likely to be susceptible to these allelochemicals. The dynamics of release of phytotoxins revealed periodic rise in their level that eventually started declining after 4 weeks. It seems that allelochemical release into the rhizosphere through residue decomposition is a function of time as well as concentration. Decline in the levels of these phytotoxins is due to a variety of physico-chemical and biological transformations upon entering into the soil phase as proposed by Blum et al. (1999).

Crop residues suppress weeds through allelopathic interference as well through their physical smothering. The residues not only suppress weeds but also have a positive bearing on the physical and biological characteristics of the soil, and add to the nutrient status of soil. Application of allelopathic crop residues in agro-ecosystems may help reduce reliance upon herbicides. Further investigations into the allelopathic potential of other residues along with different herbicides under varying crop and environmental conditions need to be conducted.

\section{LITERATURE CITED}

ANJUM, T.; BAJWA, R. A bioactive annuionone from sunflower leaves. Phytochemistry, v. 66, n. 16, p. 1919-1921, 2005 .

ANJUM, T;; BAJWA, R. Field appraisal of herbicidal potential of sunflower leaf extract against Rumex dentatus. Field Crop Res., v. 100, n. 2-3, p. 139-142, 2007.

BHOWMIK, P. C. INDERJT. Challenges and opportunities in implementing allelopathy for natural weed management. Crop Prot., v. 22, n. 4, p. 661-671, 2003.

BIRKETT, M. A. et al. Does allelopathy offer real promise for practical weed management and for explaining rhizosphere interactions involving higher plants. Plant Soil, v. 232, n. 1-2, p. 31-39, 2001.

BLUM, U. et al. Evidence for inhibitory allelopathic interactions involving phenolic acids in field soils: concepts vs. experimental model. Crit. Rev. Plant Sci., v. 18, n. 5, p. 673-693, 1999.
BOGATEK, R. et al. Sunflower allelochemicals mode of action in germinating mustard seeds. In: HARPER, J. D. I. et al. (Eds.). Establishing the scientific base. In: WORLD CONGRESS ON ALLELOPATHY, INTERNATIONAL ALLELOPATHY SOCIETY, 4., 2005, Wagga Wagga.

Proceedings... Wagga Wagga, 2005. p. 365-369.

CHEEMA, Z. A.; KHALIQ, A. Use of sorghum allelopathic properties to control weeds in irrigated wheat in a semi arid region of Punjab. Agric. Ecosyst. Environ., v. 79, n. 2/3, p. $105-112,2000$.

CHEEMA, Z. A. et al. Use of allelopathy in field crops in Pakistan. In: HARPER, J. D. I. et al. (Eds.). Establishing the scientific base. In: WORLD CONGRESS ON ALLELOPATHY, INTERNATIONAL ALLELOPATHY SOCIETY, 4., 2005, Wagga Wagga. Proceedings... Wagga Wagga, 2005. p. 550-553.

CHOU, C. H. Role of allelopathy in plant biodiversity and sustainable agriculture. Crit. Rev. Plant Sci., v. 18, n. 5, p. 609-636, 1999.

GALLANDT, E. et al. Improving soil quality: implications for weed management. J. Crop Produc., v. 2, n. 1, p. 95-121, 1999.

HARBORNE, J. B. Phytochemical methods: A guide to modern techniques of plant analysis. 2.ed. London: Chapman \& Hall, 1973. p. 279.

HARTLEY, R. D.; BUCHAN, H. High performance liquid chromatography of phenolic acids and aldehydes derived from plants or from decomposition of organic matter in soil.

J. Chromatol., v. 180, n. 1, p. 139-143, 1979

HOLAPPA, L. D.; BLUM, U. Effects of exogenously applied ferulic acid, a potential allelopathic compound, on leaf growth, water utilization, and endogenous abscisic acid levels of tomato, cucumber, and bean. J. Chem. Ecol., v. 17, n. 5, p. 865-886, 1991.

KECK, R. W.; HODGES, T. K. Membrane permeability in plants: changes induced by host specific pathotoxins Phytopathology, v. 63, n. 2, p. 226-230, 1973.

KHANH, T. D. et al. The exploitation of crop allelopathy in sustainable agricultural production. J. Agron.Crop Sci., v. 191, n. 3, p. 172-184, 2005.

LEATHER, G. R. Sunflower (Helianthus annuus) are allelopathic to weed. Weed Sci., v. 31, n. 1, p. 37-42, 1983.

MACIAS F. A. et al. Bioactive terpinoids from sunflower leaves cv. Peredovick. Phytochemistry, v. 61, n. 6, p. 687-692, 2002. 
OLMSTED, C. E.; RICE, E. L. Relative effects of known plant inhibitors on species from first two stages of old field succession. Southwestern Natur., v. 15, n. 1 p. 165-173, 1970 .

SÁNCHEZ-MOREIRAS, A. M. et al. Allelopathic evidence in the Poaceae. Bot. Rev., v. 69, n. 3, p. 300-319, 2004.

SINGH, H. P. et al. Allelopathic interactions and allelochemicals: new possibilities for sustainable weed management. Crit. Rev. Plant Sci., v. 22, n. 3/4, p. 239$311,2003$.
UREMIS, I. et al. Allelopathic potential of residue of 6 brassica species on johnson grass [Sorghum halepense (L.) Pers.]. Afr. J. Biotechnol., v. 8, n. 15, p. 3497-1501, 2009.

WEIR, T. L. et al. Biochemical and physiological mechanisms mediated by allelochemicals. Curr. Opin. Plant Biol., v. 7, n. 4, p. 472-479, 2004.

WESTON, L. A. Utilization of allelopathy for weed management in agro-ecosystems. Agron. J., v. 88, n. 6, p. 860-866, 1996. 